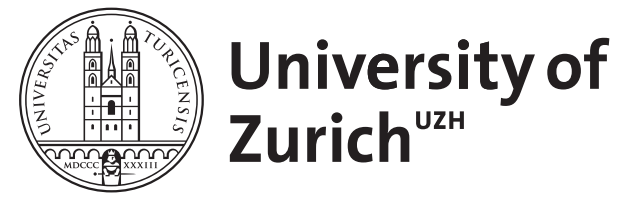

\title{
Orality, literacy and performativity of Arthurian texts
}

Trachsler, Richard

DOI: https://doi.org/10.1515/9783110432466-018

Posted at the Zurich Open Repository and Archive, University of Zurich

ZORA URL: https://doi.org/10.5167/uzh-144413

Book Section

Published Version

Originally published at:

Trachsler, Richard (2017). Orality, literacy and performativity of Arthurian texts. In: Tether, Leah; McFayden, Johnny. Handbook of Arthurian Romance : King Arthur's Court in Medieval European Literature. Berlin: De Gruyter, 273-291.

DOI: https://doi.org/10.1515/9783110432466-018 


\section{Richard Trachsler}

\section{Orality, Literacy and Performativity of Arthurian Texts}

Orality, literacy, performance and performativity are today thriving fields of research. Categories such as orality and literacy are of interest to anthropologists and classicists, historians and philologists who all have been successfully exploring data ranging from Ancient Greece to contemporary cultures in the Middle East. From these general studies emerged a rather polarized picture, with some civilizations being characterized by orality and others already in command of literacy. This "Great Divide", as it is sometimes termed, forces an evolutionary look at the facts and opens a time span of more than a millennium where things, in some ways, are always "in transition", shifting from archaic orality to modern literacy. ${ }^{1}$ To the scholar concerned mainly with the western Middle Ages, this binary opposition is of little use: since the medieval period is obviously marked by both orality and literacy, it is an aural culture. Slowly but steadily, over recent decades, a new consensus regarding the focus of our studies has emerged: we need to account for the various ways in which the written word was embedded in orality. From the interest in orality stems the relatively new sector of medieval performance studies, since performance gives the text not only a voice, but also a body. ${ }^{2}$

As keywords in medieval studies they may have been coined only quite recently, but terms such as "performers", or, as they were once called, "jongleurs", "minstrels" and "bards", entered the scholarly debate as soon as philology

1 The critical bibliography on the subject is enormous: Richter (1994), though concerned mainly with the period prior to vernacular literature, contains a useful introduction to the problem. For the Middle Ages, see Paul Zumthor's oeuvre which continues to be very influential in France: Zumthor (1984; 1987). For the German domain, see Green (1994). Coleman (1996) gives an excellent account of prior research and offers a refreshing look at the problem. I also recommend it as a starting point for its personal and determined prose.

2 The epicentre of medieval performance studies is in New York: see the volumes by Birge Vitz et al. (2005), Krueger and Burns (2007) and Duys et al. (2015). The New York team is also involved in several websites, such as the Youtube platform dedicated to "Medieval Tales in Performance": <https://www.youtube.com/channel/UC2wz1uR1S193vNMWML2Ieyw>, the showcase "Performing Medieval Narrative Today: A Video Showcase", and, exclusively for Arthurian material, "Arthurian Legend Performed": < http://vimeo.com/ArthurPerform>.

Richard Trachsler (University of Zurich)

DOI $10.1515 / 9783110432466-018$ 
emerged as a discipline of its own in late nineteenth-century academia. And with them came orality. Scholars were trying to provide a new scientific framework not only to account for the origins, but also for the changes in language, motives and, more generally, texts, plots and stories. It was in that context that the debate on the origins and circulation of the chanson de geste and Arthurian literature arose and the first models regarding composition and transmission were elaborated. Since those scholars were rightly concerned mostly with the Sitz im Leben [literally: setting in life] of the documents they were reading and explaining, their models relied heavily on emblematic figures such as the troubadour, the cleric, the jongleur and the minstrel. These tutelary figures were responsible for the invention and the transmission of medieval literature and, thus, for what modern critics would later term performance.

To the generation of Gaston Paris, Wendelin Foerster, through to Gustav Gröber, Joseph Bédier and, especially, Edmond Faral in the late-nineteenth to early-twentieth century, jongleurs and bards were key figures for the understanding of medieval literature, since jongleurs, somehow, might have circulated some form of chanson de geste before the Oxford version of the Chanson de Roland, just as the Celtic bards somehow must have told the stories that Marie de France and Chrétien de Troyes would then have taken up and elaborated. This situation partly explains why the discussion regarding orality has not always separated the two distinct moments of composition and delivery of vernacular literature (Green 1990, 267-280).

On the positive side, one cannot fail to acknowledge that the pioneers of our discipline, by distinguishing different kinds of performers specializing in different kinds of literature, have established a conceptual framework that accounts for differences, on grounds of content, form and milieu, amongst the various types of medieval performances. The jongleur, the cleric, the bard and the troubadour are all tutelary figures of different genres, and they work in distinct environments, such as cities, markets and courts. ${ }^{3}$ The genres they performed, by virtue of their formal and thematic differences, probably indicate distinct forms of composition, transmission and circulation of texts. This way of putting the matter, if we think of the distinctions regarding performers and texts not as rigid categories but more as shiftable parameters, definitely helps us to assess medieval performance. The performers can move from one milieu to another, and their repertoire can be adapted, or not, since there is no need to assume that a given audience will only respond to one kind of text. This more open way of looking at medieval

3 See the remarkable pioneer study by Faral (1910a) for a general synthesis on the question after three generations of scholarship. 
performance also allows us to account for the co-existence of different forms of performance during the Middle Ages and beyond, and also helps to prevent a teleological vision of the evolution of performance in the period, which invariably shifted from oral to written and from more social to individual forms of reading at a uniform pace all across Europe.

The Italian cantari offer a case in point. These texts, which to our knowledge are specific to the Italian sphere, are the unique instance in which Arthurian material seems to have continued to be delivered by professional singers in Renaissance Italy and beyond. The cantari, short and self-contained episodes usually drawn and adapted from longer accounts, range from four hundred to several thousand lines organized in ottava rima, eight-line stanzas, following a pattern used also by Boccaccio in his Tesiada and Ninfale and later, of course, by Pulci, Boiardo and Ariosto. Clearly, these short stories were sung by canterini [singers] whose presence in public places in the South of Italy was still recorded in the nineteenth century, although we do not know how exactly the recitations in the Middle Ages would have taken place, since the texts preserved in the manuscripts certainly seem to allow for improvisation during performance. As far as we can tell from these documents, there was no obvious distinction made between cantari of Arthurian content and others based on Carolingian or classical material, which are sometimes contained in the same manuscripts (Bendinelli Predelli 2014, 105-120). ${ }^{4}$ Arthurian cantari are cantari before they are Arthurian. ${ }^{5}$

It may seem arbitrary that the present overview will concentrate on material in French, but, in medieval times, such matter was rather central and an important vector for the dissemination of literature and culture in general on a European scale. Many aspects should thus be adaptable also to other languages and contexts. One should keep in mind though that, although the general political and social organisation in Europe was fairly homogenous throughout the Middle Ages, performing Arthurian literature was unlikely to have been perfectly identical in Britain and other parts of the continent, and might have taken quite different forms, particularly in Scandinavia and in Sicily. The second point that should be kept in mind is that Arthurian literature is not a separate entity in the general panorama of medieval texts. Arthurian literature was probably circulated

\footnotetext{
4 How this oral poetry was fixed in writing is a complex issue; see Degl'Innocenti (2008) and the review of this title by Morato (2011, 194-199). I have not been able to consult Luca Degl'Innocenti's latest book (2016), but it purports to further the argument.

5 Locally- or regionally-specific forms of performance, linked to very specific genres, might survive or arise and it would probably be unwise to make generalizations on a matter we know comparatively little about.
} 
in exactly the same way as other texts presenting the same formal criteria, such as non-Arthurian romance or non-Arthurian lais. More significantly, there is no such thing as an "Arthurian performance": Arthurian lais would not have been delivered in an identical way to Arthurian verse romance or Arthurian prose, which would again be something entirely different. The key to the understanding of how Arthurian literature was circulated lies not in the materia, but in the genre. Before turning to the texts, it might be helpful to start with an overall presentation of the aspects regarding the orality and literacy of Arthurian literature with some contextual facts about its performance and transmission.

\section{Enacting}

When it comes to the performance of Arthurian literature, the most obvious place to look might be the stage. For the medieval period, there is little to be seen there: in France and all the Latin countries, there is no trace of the existence of any form of Arthurian drama, and in the German tradition the only appearances of Arthur on stage are in the comic context of the late medieval Fasnachtsspiele staging a chastity test set at Arthur's court. Only three such plays -all based on the same theme, but using different instruments (the horn, the coat and a crown) - are known, while a fourth play is known only by its title (Kindermann 1966 [1957], 429; Moser 1984; Tailby 2000). Only in Britain is there a "serious" theatrical tradition based on Arthurian texts, but again, this kind of entertainment emerges only in early-modern times (Lupack 1991). Throughout the medieval period, there are, though, the very common forms of the pas d'armes [passage of arms] and the tournament, where knights and ladies, but also entire towns, would enact and perform Arthurian characters and episodes.

This kind of entertainment can vary greatly: it might involve only a small group of knights, or an entire court or town. The duration would also range from a more concise event to gatherings across several weeks. All across Europe and beyond, chivalric events, called Round Tables, were organized. Usually the event would involve tournaments and some form of entertainment, loosely inspired by Arthurian or otherwise novelistic material, but the spectacles would become so common and popular that the designation "Round Table" often served as simple synonym for “tournament” (Stanesco 1988, 95). These Round Tables are clearly an international phenomenon that developed wherever there was a knightly culture 
in the Western world, including the Baltic coasts and the Holy Land. ${ }^{6}$ Philippe de Novare, a knight who took part in the war in Cyprus and whose testimony seems reliable, reports that, in 1224 in Beirut, knights had "contrefait les aventures de Bretaigne et de la Table Ronde” (Philippe de Novare 1913, 7) [mimicked the adventures of Brittany and the Round Table] in celebration of the knighting of the two sons of a local nobleman. As for Gérard de Montréal, who also travelled to the East, he records that, in Acre in 1286, tournaments were held where the participants "contrefirent la Table Reonde [...] et contrefirent Lanselot, et Tristan et Pilamedes et moult d'autres jeus bias et delitables et plaissans" (Raynaud 1887, 220, §430; see also Pickford 1960, 248) [mimicked the Round Table [...] as well as Lancelot, Tristan and Pilamedes and many other similar delightful, pleasant games]. In most cases, we do not know, unfortunately, in what the contrefaiture, the "imitation", of the Arthurian knights actually consisted. But Lodewijk van Velthem, a Dutch historiographer of the fourteenth century, in his Spiegel Historiael, gives a quite extensive account of a Round Table, organized by Edward I, King of England. ${ }^{7}$

It is possible that Lodewijk van Velthem, who also adapted French Arthurian romances into Dutch, embellished or invented parts of the event, but it still remains an instructive piece of evidence, since it must have seemed plausible to his readers and is not very different from other accounts of similar events that have come down to us. ${ }^{8}$ Lodewijk states that for Edward I's marriage with Eleanor of Castile, some of his knights were installed as members of the Round Table and took the names of Arthurian characters, such as Gawain and his brothers, Agravain, Mordred and Gaheriet, followed by Lancelot, Bohort and Lionel, as well as Kay and Perceval, all impersonated by King Edward's best knights. Sir Kay, in particular, played a comic part, with quite lengthy dialogue and several practi-

6 The Artushöfe established by Hanseatic merchants along the Baltic Sea do not involve people enacting given Arthurian episodes, but are buildings established and maintained by societies whose members would think of themselves as a forming a kind of chivalric brotherhood. On this very interesting phenomenon, see Selzer (1996) and Kugler (2010). There is evidence, too, for Arthurian activities in the north, as was stated some time ago by Schlauch (1959). See also Wilhelm (1988).

7 The text of Lodewijk van Velthem's chronicle is conveniently edited and translated in Johnson and Claassens (2007).

8 Huet (1913) considered that Lodewijk had invented the entire episode, drawing from literary sources. In his influential contribution, Loomis (1953, 114-117 and 118-119), on the other hand, was inclined to take the account as fact. For a commentary on the passage, see Barber (2008, 84-99, especially 92-93). The most recent study is by Summerfield (2015), who gives an up-todate bibliography. 
cal jokes involved, such as cutting saddle-girths. Edward and Eleanor's marriage would have taken place in 1254 at the monastery of Las Huelgas, Burgos. Neither the chronology nor the circumstances of Lodewijk's account match the historic setting. On the whole, though, the description he gives of the actual spectacle nevertheless resembles reasonably well what Sarrasin, an otherwise undocumented author, recalls in his Roman du Hem, where the term roman in the title merely indicates that the text is an account in romance language. It could more accurately be described as a "'reportage en vers' qui a la valeur d'un document historique" [report in verse, which has the value of a historical document]. ${ }^{9}$

The Roman du Hem relates a tournament that took place in Hem-Monacu, in the region of Artois, over three consecutive days, from 9-11 October 1278. The event offered jousts alternating with several Arthurian interludes. Together with the Tournoi de Chauvency, organized in 1285 and recorded by Jacques Bretel, it contains the most detailed description of such a social event. ${ }^{10}$ Unlike the royal marriage recorded by Lodewijk, participants mostly include members of the local noblesse, whose foremost representative was Count Robert II of Artois, the nephew of Saint Louis, King of France, and the Duke of Lorraine, Ferry III. The fact that their tournament would follow a similar scenario to the one recalled in the Dutch chronicle seems to indicate a European aristocratic form of entertainment where real people, not actors, would perform as Arthurian characters. In this case, the anonymous sister of Aubert de Longueval, one of the organizers of the encounter, would play the part of Queen Guinevere, and it was she who also commissioned the text, while Robert II of Artois would be Yvain, the Knight with the Lion. Soredamor would also make an appearance and again Sir Kay would play a comic part; of course there was also the lion, presumably played by an actor wearing a mask and a costume rather than using a real lion, since he was expected to move through the crowd and to pose and growl in accordance with the plot (Freeman Regalado 2005, 114). ${ }^{11}$ Of particular interest here is that Arthurian romance not only provides the overall frame and reservoir from which the author drew his inspiration for the interludes, but also that the Roman $\mathrm{du}$ Hem contains precise textual allusions to Chrétien de Troyes. Not only does Sarrasin mention

9 This formula is used by Henry, who produced the impeccable edition of Le Roman du Hem (Sarrasin 1939, XII). The text has been much studied in recent years; see Vale (1982); Freeman Regalado (2005; 2007).

10 The Tournoi de Chauvency is not based on Arthurian material and shall not be discussed here. For an introductory assessment, see the excellent edition by Delbouille (Bretel 1932). For an extensive overview, see the recent volume by Chazan and Freeman Regalado (2012).

11 One might add the lions were kept even in the ménageries of smaller castles and thus could have been used if so wished. See also Lievois and Van den Abeele (2012). 
him respectfully by name, and explicitly mentions his Conte du Graal, but he also quotes, almost verbatim, several lines from Chrétien's romances (Sarrasin 1939, XII, LVI and n. 1). During a joust on the second day, Sir Kay comically shouts "Or est venu qui aunera” (Sarrasin 1939, 1. 1906) ["Here comes the one who will measure all others"], which is the exact line that welcomes Lancelot at the tournament of Noauz in Chrétien's Chevalier de la charrette (Freeman Regalado 2005, 106). ${ }^{12}$ The public would, we can assume, recognize the quotation and perhaps even verbally participate in the interlude, as the reaction of the damsels in the scene would suggest, since they mock Kay for his self-confidence.

Most of the reports regarding tournaments and Round Tables of this kind are unfortunately not very elaborate, but there is no doubt that Arthurian influences continued to fashion these kinds of spectacles in the later Middle Ages, especially in the form of the pas d'armes, a ritualized form of combat, based on literary reminiscences, where knights would joust in pairs, as opposed to Round Tables where the fighting would involve groups and a general mêlée. Mathieu d'Escouchy (1863-1864, 251-252) reports that, in 1449 near Saint-Omer, the Pas d'Armes de la belle Pèlerine was organized. The challenge was to defend a travelled spot, such as a city gate or bridge, against whoever else put himself forward. The defender would post himself near the designated spot during a period of time publicly announced in advance - on this occasion it would be from the "xve jour de juillet jusques à la feste de l'Assumpcion Nostre-Dame my aoust" (Mathieu d'Escouchy 1863-1864, 252) [fifteenth day of July until the feast of the Assumption of Our Lady in August] - and have two shields hanging outside his tent. One would be Lancelot's, the other Palamède's. Whoever wished to challenge the defender would have to touch one of the two shields: Lancelot's if the opponent wished to fight using a lance, and Palamède's for a fight using swords. The fights would take place on a Wednesday. However, challengers could reserve their turn on any day except Friday, from prime (sunrise) to noon, by contacting a herald and then blowing a horn made available to the challengers. One immediately sees how the preparation and the fight are staged and ritualized by literary tradition. The Pas d'armes de la belle Pèlerine pays homage to an episode of the Prose Tristan, in which Alexandre l'Orphelin undertakes a similar test for a damsel with precisely that name (Pickford 1951, xvj and n. 70).

Chronicles usually just give summary descriptions of these events, a digest, or a review, but sometimes the original "scenario" has come down to us, too. In these fuller versions of the pas d'armes, of which we have several examples, there seems to be little room for improvisation. The rules are very explicitly laid out and

12 Henry's note to this line does not include this reference. 
every eventuality is discussed. Sometimes, the text even specifies what has to be said in a particular circumstance. ${ }^{13}$ It is, of course, difficult to know, based on the evidence of the "script", what the knights in the field actually said, especially since the text contained in the surviving manuscripts breaks down into different redactions, which would suggest that there was room for the adaptation of what otherwise seem like concrete scenarios. All these forms of enacting Arthurian episodes assume a good knowledge of the characters, the plot and the general setting. Obviously, such knowledge could only be gathered by reading the stories or listening to someone telling them.

\section{Reading and listening}

Jean Froissart, in an often-quoted passage from his chronicles, provides the only explicit account of how an author delivered his work. During the winter months of 1388-1389, Froissart was staying in Orthez at the court of Gaston Fébus, Count of Foix. Gaston, a passionate hunter who would return late from his hunting expeditions and then dine with his court, would order Froissart to join him every night at midnight and read to him from his Roman de Meliador, the last Arthurian verse romance ever written in French. Meliador, as Froissart points out, had been composed for his former patron, Duke Wenceslas of Bohemia, himself a poet, whose lyrics Froissart has inserted in the romance (a point to which I return later):

L’accointance de li a moy pour ce temps fu telle que je avoie avecques moy aporté un livre, le quel je avoie fait a la requeste et contemplacion de monseigneur Wincelaus de Boesme, duc de Lucembourc et de Braibant, et sont contenus ou dit livre, qui s'appelle de Meliader, toutes les chansons, balades, rondeaulx, virelaiz que le gentil duc fist en son temps, lesquelles choses parmi l'ymaginacion que je avoie en dicter et ordonner le livre, le conte de Fois vit moult volentiers; et toutes les nuit aprés son soupper je lui en lisoie, mais en lisant, nul n'osoit parler ne mot dire, car il vouloit que je feusse bien entendu, et aussi il prenoit grant solas au bien entendre. Et quant il cheoit aucune chose ou il vouloit mettre debat ou arguement, trop volentiers en parloit a moy, non pas en son gascon, mais en bon et beau françois. (Froissart 2007, §13, 188-189) 14 $^{14}$

[Our acquaintance during that time was such that I brought with me a book that I had made at the request and under the supervision of Wenceslas of Bohemia, Duke of Luxemburg and Brabant. And the book, called Meliador, contains all the songs, ballads, rondeaux, virelais

13 See the introductory remarks of the Le Pas du Perron fée, which is not specifically an Arthurian text (Horn et al. 2013).

14 Froissart gives a similar account of the events in his Dit dou Florin (1979, 11. 293-309 and 342-389). 
the noble Duke had composed back then. The Count of Foix was happy to see my project regarding the writing and organization of the book. And each night after dinner I used to read to him parts of it, and while I was reading, no one dared to speak or say anything, because the count wished that I should be heard, so great was his pleasure in hearing it. And when there was a point he wished to discuss or debate, he would gladly talk to me in good and nice French, not in his native Gascon.]

This account, stating the privileged position of Froissart at the court of a potential patron who would intervene and discuss the poem that was being recited directly by the author, might be exceptional. ${ }^{15}$ What is not exceptional is the practice of noblemen having stories read for their entertainment or instruction. In the second half of the sixteenth century, Charles IX, King of France, would still have people reading to him:

Tantost [le roy] se faisoit lire, ou des vers François, ou les Annales de France, ou Giron le Courtois: quelquefois des anciens Historiens. (Sorbin 1574, f. 30v) ${ }^{16}$

[Sometimes [the king] wished to be read to: it could be verses in French, or the Annals of France, or Guiron le Courtois; sometimes the works of ancient historians.]

These sessions were private, but not individual. Selected members of the household or of the court would attend and listen. Presumably, the person reading had special skills, but was not necessarily a professional entertainer. In the case of King Charles V, we know he liked his librarian, Gilles Malet, to read for him (Coleman 1996, 22).

Illustrations in manuscripts show precisely this: reading scenes involve the public. There is always a reader with a book in front of an audience that would not only listen, but also watch him. It seems reasonable to suppose that he might have adapted his voice for direct speech and accompanied his lecture with gestures, but we have little evidence to support this. We do not know how such sessions were organized or how long they took. Froissart went to see Gaston de Foix every night during his stay at Orthez. Given that approximately one thousand octosyllables can be recited per hour, depending, of course, upon the amount of

15 In fact, the discussion of such sessions is quite similar to what Nykrog (1996) has assumed to be the primary mode of reception of Chrétien's romances.

16 The same can be said of the court of Burgundy a century earlier: "Très renommé et vertueux prince Philippe duc de Bourgogne a dès long-temps accoutumé de journellement faire devant lui lire les anciennes histoires." [The very renowned and virtuous Prince Philip, Duke of Burgundy, has been long accustomed to having ancient [hi]stories read to him daily]. Prologue of the Histoire abrégée des Empereurs written by David Aubert for Philippe le Bon en 1457, quoted from Petit (2007, 60). 
interaction with the reader, reciting Meliador would have taken up several weeks if the session started at midnight and went on for, say, two hours with a few interruptions. ${ }^{17}$

On a larger scale, during feasts and celebrations, professional performers would be invited, sometimes in huge numbers. For the knighting of Prince Edward, in 1302, more than one hundred and nineteen minstrels, most of them musicians, are recorded as having been in attendance. ${ }^{18}$ On other occasions, for instance the marriage of Princess Margaret to Jean of Brabant a decade earlier, four hundred and twenty-six minstrels were even paid (Bullock-Davies 1978, 12). It is impossible to know how and what they performed, but some assumptions can be made. ${ }^{19}$ It would have been impossible, given both the number of minstrels and the nature of the audience involved, to perform entire romances or even one of the longer lais, as the audience would most likely have been disruptive. Extended recitation might have been possible in a more isolated castle or at a village gathering, where there was less competition amongst the minstrels and more stability in the public's attention span. But even then the performer must have been inclined, in order to keep the audience's interest, to modify his performance to suit, and adapt to, the present circumstances. "To do so, he would have needed to deliver short fragments and to modify them appropriately.” (Taylor 2002, 66)

That is exactly the reproach an author such as Chrétien de Troyes makes against the professional conteurs who tell tales for a living ("cil ki de conter vivre vuelent", Erec et Enide, 1. 22). ${ }^{20}$ They "cut into pieces" and "spoil" (depecier et corronpre, 1.21) the author's romance. The storytellers, during their performance, would make use as they pleased of their source material, by cutting it, editing it or rearranging it in order to fit the audience's requests and preferences. Such individually arranged sequences also explain why the répertoires de jongleurs that are so frequently inserted into the descriptions of scenes of feasts in romances contain such a great variety of titles, including works we would not associate with minstrels at all, such as the Matter of Rome. ${ }^{21}$ When we go through the "titles"

17 The numbers are mine, based on personal experience. Rychner stated slightly higher numbers for the séance épique [epic session], but, wisely, did not specify how many hours such a séance might take (Rychner 1957, 48-49 and 54). Given the amount of artists and scholars actually performing medieval texts, one is surprised that there is not more statistical data available. 18 For a superb study of the documents regarding this well-documented knighting see Bullock-Davies (1978).

19 I here follow Taylor (2002, 65-69) whose suggestions are cautious, yet firm and helpful.

20 All references are to Chrétien de Troyes (1952).

21 For a presentation and discussion of the range of competence of a jongleur, see Faral (1910a). For this paragraph, I refer to Duggan (1989; 1989-1990). It is based essentially on the repertoire 
given in such descriptions contained in romances or in the Occitan ensenhamens [didactic poems], we are actually mostly confronted with names of famous characters, rather than titles in the modern sense. One minstrel tells the story of Ulysses, another recalls the adventures of Erec and so on. The roll of characters contained in Flamenca, for instance, even lists Merlin and Mordred.

During such feasts, where so many jongleurs assembled in one single place, it is unlikely that they were presenting the works in extenso and in an orderly fashion. There would be too much noise and agitation and no one could sustain attention for the necessary duration (cf. Hogenbirk, infra). It is thus perfectly possible that references to the famous characters actually relate to "excerpts" of longer texts the performers turned into short stories or that, quite simply, they would just recite a part of a long romance (Duggan 1989, 57). ${ }^{22}$ Whether these recitations were largely improvised or read from a book remains an open question, one which allows for many answers. There is certainly one type of performance where improvisation is minimal and a second type, which allows for extemporization and composition on the spot, leaving space, between them, for a large variety of possibilities. One is naturally tempted to associate the stable representation, perhaps linked to written text, with a genre like romance and the second, a more improvisational - or rather, composing in performance - mode, with an "oral" genre like the chanson de geste. But a careful look at epic texts shows that very often the narrators actually say that they are standing before their audience and reading a text aloud, as opposed to reciting it by memory, so that the book(s) would play an important role during the performance. ${ }^{23}$

\section{Manuscript evidence}

Given the aural culture of the Middle Ages, we have been assuming here that texts were only read aloud. It is true that silent reading was a reality, though

contained in Flamenca, one of the longest non-autonomous lists of texts allegedly performed by minstrels. But a similar picture also emerges from the three short satirical pieces going by the title of Deux Bourdeurs Ribauds and the Occitan ensenhamens. For the text, see Faral (1910b, 83-105) and a discussion in Schulze-Busacker (1984). On the ensenhamens, see Pirot (1972) and Monson (1981).

22 "It is generally accepted that medieval poems were not necessarily recited in full and that recorded repertoires often seem to indicate selected episodes rather than complete narratives." (Hunt and Bromiley 2006, 113)

23 See the convincing argument set out by Tyssens (1966). 
it remained exceptional until early-modern times. ${ }^{24}$ But are there any traces in the manuscripts that would indicate that they were conceived for public recitation? Again, the texts and situations suggest it might be wise to allow for several answers. It is clear that lavishly illustrated manuscripts, with titles, rubrics and tables of contents were made to be looked at, rather than heard. Yet it is not absurd to imagine that the reader can show and share an image with his public in an intimate circle of listeners. Studies of manuscripts, some of which contain Arthurian verse romances, have shown gradual changes in layout and iconographic cycles indicating a shift from aural to visual reception (Busby 1993). On the other hand, the increasing amount of punctuation and improvements in word separation suggest that these manuscripts were intended to be read and, presumably, read aloud, since this kind of information would be particularly precious for somebody performing the text. ${ }^{25}$ Especially in the light of the complex syntax of the prose romances and their new stylistic devices, such as emergent direct discourse, there is a sudden shift from indirect into direct speech, which would obviously present a "trap" for any performer. Such grammatical indications, usually in the form of punctuation, would therefore be most welcome by the reader. Yet the evidence presented by the manuscripts is not very conclusive, as some versions simply omit such stumbling blocks altogether, or convert them into either direct or indirect discourse. ${ }^{26}$ The manuscripts of the Dutch translation of the Lancelot actually do contain some marginal annotations to facilitate the oral delivery of the text, but curiously they do not seem to focus on emergent direct discourse. ${ }^{27}$

There is one kind of evidence, though, that is rarely quoted but which is very helpful in this instance, since it would prove the aural reception of both Arthurian verse and prose romance until a very late stage. One of the formal innovations introduced by authors of the verse romance in the early-thirteenth century is the insertion of lyric pieces into the octosyllabic body of the text. ${ }^{28}$ These songs, as far as we can tell, already existed prior to the composition of the romance. They

24 The persistence of reading aloud was recognized in early criticism by Balogh (1927). On silent reading, see Saenger (1997), but consult also the comments by Coleman (1996, 21-23).

25 I follow Busby $(2005,61)$. A similar result is reached for the German tradition, based on a large number of manuscripts, by Palmer $(2005,86)$ : "the use of the punctus elevatus in these manuscripts is not in itself an indication that the poems were to be intoned in the manner of liturgical recitative, but it is a strong indicator that the manuscripts offer texts that are to be performed."

26 The term "emergent direct discourse" was coined by Lacy (1994).

27 As shown by Brandsma (2000).

28 For a general presentation of the phenomenon, see Boulton (1993). 
circulated as songs and were known as such, in that people knew their words and their melodies. Escanor by Girart d'Amiens, for instance, contains four refrains all sung by Escanor and his suite on their way to Arthur's court. These refrains are also transmitted, in complete versions, in manuscript collections of lyric material. Yet, these refrains are woven in to the octosyllabic texture of the narrative, with the last line before the insertion rhyming with the first line of the song, and the same technique is used at the end of the song. The interesting point regarding performance is that these songs, quite clearly, were meant not only to be read, but also to be sung. In the only manuscript of Escanor that has come down to us, blanks for musical notation have been left by the copyist. The notes have never been inserted, but the person who prepared the manuscript obviously considered that it would be better to include the melody and thought he had a fair chance of obtaining the tune, and therefore he left some space around the text. ${ }^{29}$ The case is not unique at all, as many non-Arthurian manuscripts - including, for instance Girart's Méliacin - present the same features. The notation of the melody or blanks clearly prove that the whole romance was read aloud, otherwise it would make little sense to insist on the lyric insert. ${ }^{30}$ The interesting point here is that the manuscripts of Arthurian prose romances would respect this tradition. Some manuscripts of the Prose Tristan contain the melody of the lais or leave blanks for the notation. ${ }^{31}$ Even in this case, where the song was no longer an imported, pre-existing piece, but invented ex novo for the new romance, the creation would include not only the words, but also the music. In other words, these manuscripts would not simply allow, but rather call for, an aural reception.

\section{Internal evidence?}

We have not touched, yet, on the internal aspects of the performance and reception of Arthurian literature. Thematic and formal features might also indicate literacy or orality. Rhetoric, style and the general poetics of Arthurian verse and prose romances have been studied in detail, particularly the persona of the

29 For details, see Girart d'Amiens (1994, 51-54).

30 Jean Froissart's Meliador, the only other Arthurian verse text to contain lyric insertions, is an even stronger case in point. Froissart used pieces written by Wenceslas, whose favour he wished to attract by providing a shrine for his chansons, balades, rondeaulx, virelaiz, i.e. genres that were clearly still sung and not just recited.

31 For an introductory approach see Fotitch and Steiner (1974). The lyric insertion of the Guiron-Cycle have been edited by Claudio Lagomarsini (Guiron le Courtois 2015). 
narrator and the authorial voice, which have attracted much critical attention since the early 1970s, when literary studies started to focus almost exclusively on the reflexivity of literature and its tendency to stage its own creation. For verse romances, especially those of Chrétien de Troyes, but also Marie de France's lais, phenomena such as mise en abyme, mise en écriture and interlace of narrative voices of all kinds have been thoroughly investigated. ${ }^{32}$ Whereas earlier scholarship concentrated more on showing how Arthurian romance or lais articulated a moral or social lesson of an author or a class, recent studies have stressed the conflicting voices within a given text, and a fortiori, within the opera omnia of an author, or, even, an entire genre. In the case of Chrétien de Troyes and Marie de France, critics have insisted on the fact that their texts shift from:

the fable with a moral to the problem romance. In problem romances, the narrator's point of view looms large, as do the points of view of characters in the plot. They provoke audiences, eliciting reactions form a personal point of view as well. (Kelly 2005, 61) ${ }^{33}$

It is not unlikely that medieval audiences, such as Gaston de Foix listening to Froissart's Meliador, would react to what they were hearing, and that the authors, by including scenes like Calogrenant's tale for discussion within the romance, would favour such debates. But we cannot know what was said during or after those performances.

It might be appropriate, though, to point out an additional feature of Arthurian verse production that offers considerable potential for further research, and which might cast some light on the performance and even composition of Arthurian verse romances: recent studies have shown that Arthurian verse romances and medieval French texts in octosyllables in general contain a conspicuous amount of hemistichs or even entire verses that occur several times in the same texts. ${ }^{34}$ Not only do such repetitions occur within the same text, but nearly identical lines can also be found in completely unrelated texts. Put another way, we are confronted with formulaic material, as might be expected in an aural context.

As long as studies on oral poetry were concerned mainly with the chanson de geste, medievalists did not focus on courtly romance. When scholars conducted the first computer-assisted research on a large corpus of medieval French litera-

32 For a recent overview regarding Chrétien de Troyes, see Kelly (2005).

33 On the potential of Arthurian texts to trigger discussion in the audience, see Nykrog (1996). It is interesting to note Spitzer's intuition about Marie's lais (Spitzer 1930).

34 Studies on Arthurian material include Trachsler (2009) and Endress (2016). Recently, Cormier (2015) has raised similar questions regarding the Roman d'Eneas, one of the most 'learned' texts in the French corpus of romances. 
ture in the early 1970s, they succeeded in demonstrating that there exists a high concentration of formulaic material in the chanson de geste. Understandably, the octosyllabic production was not at the centre of their focus. Coincidentally, and precisely during those same years, literary scholarship began discovering the narrative devices contained in courtly romance, especially in works by Chrétien de Troyes. Again very understandably, scholars found and investigated exactly what they were looking for: traces of borrowing, quotations and intertextual relations of all kind. In other words, traces of literacy. Arthurian romance, thus, is generally considered to demonstrate that there was a high degree of literacy. If, therefore, Arthurian romance does to some extent contain formulaic material, some of these "quotations" are not "quotations" at all, but rather are simple formulas: standard wording of standard situations and some of the "literacy" of the romance would spill over into the "orality" of the chanson de geste.

This potential commonality might be linked to some shared "oral residue" which, to different degrees, informs both epic and romance literature in the Middle Ages and can be traced both in the decasyllables of the chanson de geste and the octosyllables of romance. ${ }^{35}$ It is still too early to attempt to give finite, or even general answers. But we can at least say that the presence of formulaic material seems to reflect the conditions in which Arthurian verse romances were produced and circulated from the end of the twelfth century onwards. This alone is worth further investigation.

\section{References}

Balogh, J. “Voces Paginarum. Beiträge zur Geschichte des lauten Lesens und Schreibens.” Philologus 82 (1927): 84-109 and 202-240.

Barber, Richard. "Why did Edward III hold the Round Table? The Chivalric Background." Edward III's Round Table at Windsor: The House of the Round Table and the Windsor Festival of 1344. Woodbridge: The Boydell Press, 2008. 84-99.

Bendinelli Predelli, Maria. "Arthurian Material in Italian Cantari." The Arthur of the Italians: The Arthurian Legend in Medieval Italian Literature and Culture. Ed. Gloria Allaire and F. Regina Paski. Cardiff: University of Wales Press, 2014. 105-120.

35 This point was made, but with an entirely different set of arguments, more than twenty years ago by Birge Vitz (1986; 1987; 1990). “Oral residue” is a term coined by Walter Ong, which means, in essence, a habit of thought and expression from preliterate situations, and a practice that is carried over into a new medium through the inertia or inability to dissociate the new medium from the previous one. 
Birge Vitz, Evelyn. “Chrétien de Troyes: clerc ou ménestrel? Problèmes des traditions orale et littéraire dans les cours de France au XIle siècle." Poétique 81 (1990): 21-42.

Birge Vitz, Evelyn. "Orality, Literacy and the Early Tristan Material: Béroul, Thomas, Marie de France.” Romanic Review 78 (1987): 299-310.

Birge Vitz, Evelyn. "Rethinking Old French Literature: The Orality of the Octosyllabic Couplet.” Romanic Review 77 (1986): 308-321.

Birge Vitz, Evelyn, Nancy Freeman Regalado and Marilyn Lawrence, eds. Performing Medieval Narrative. Cambridge: D.S. Brewer, 2005.

Boulton, Maureen. The Song in the Story: Lyric Insertions in French Narrative Fiction, 1200-1400. Philadelphia, PA: University of Pennsylvania Press, 1993.

Brandsma, Frank. “Emergent Direct Discourse: A Performer's Nightmare ?” “Por le soie amisté.” Essays in Honor of Norris J. Lacy. Ed. Keith Busby and Catherine M. Jones. Amsterdam and Atlanta, GA: Rodopi, 2000. 15-32.

Bretel, Jacques. Le Tournoi de Chauvency. Ed. Maurice Delbouille. Paris: Droz, 1932.

Bullock-Davies, Constance. Menestrellorum Multitudo. Minstrels at a Royal Feast. Cardiff: University of Wales Press, 1978.

Busby, Keith. "Mise en texte as Indicator of Oral Performance in Old French Verse Narrative." Performing Medieval Narrative. Ed. Evelyn Birge Vitz, Nancy Freeman Regalado and Marilyn Lawrence. Cambridge: D.S. Brewer, 2005. 61-71.

Busby, Keith. "Text, miniature, and rubric in the Continuations of Chrétien's Perceval." Les manuscrits de Chrétien de Troyes/ The Manuscripts of Chrétien de Troyes. Ed. Keith Busby et al. 2 vols. Amsterdam, Rodopi, 1993. II, 365-376.

Chazan, Mireille, and Nancy Freeman Regalado, eds. Lettres, musique et société en Lorraine médiévale: Autour du "Tournoi de Chauvency" (Ms. Oxford Bodleian Douce 308). Geneva: Droz, 2012.

Chrétien de Troyes. Erec et Enide. Ed. Mario Roques. Paris: Champion, 1952.

Coleman, Joyce. Public Reading and the Reading Public in Late Medieval England and France. Cambridge: Cambridge University Press, 1996.

Cormier, Raymond. "Indications d'oralité dans l'expression poétique du Roman d'Eneas." Romania 133 (2015): 311-327.

Degl'Innocenti, Luca. “Al suon di questa cetra." Ricerche sulla poesia orale del Rinascimento. Florence: Società Editrice Fiorentina, 2016.

Degl'Innocenti, Luca. I Reali dell'Altissimo. Un ciclo di cantari fra oralità e scrittura. Florence: Società Editrice Fiorentina, 2008.

Doss-Quinby, Eglal, Roberta L. Krueger and E. Jane Burns, eds. Cultural Performances in Medieval France. Essays in Honor of Nancy Freeman Regalado. Cambridge: D.S. Brewer, 2007.

Duggan, Joseph J. "Performance and Transmission, Aural and Ocular Reception in the Twelfth- and Thirteenth-Century Vernacular Literature of France." Romance Philology 43 (1989-1990): 49-58.

Duggan, Joseph J. "Oral Performance of Romance in Medieval France." Continuations: Essays on Medieval French Literature and Language in Honor of John L. Grigsby. Birmingham, AL: Summa, 1989. 51-61.

Duys, Kathryn A., Elizabeth Emery, Laurie Postlewate, eds. Telling the Story in the Middle Ages: Essays in Honor of Evelyn Birge Vitz. Cambridge/Woodbridge and Rochester, NJ: D.S. Brewer, 2015. 
Endress, Laura. "Orality and Textual Reworking in Floriant et Florete: Another Note on a 'Patchwork Romance'." Neophilologus 100 (2016): 1-18.

Faral, Edmond. Les jongleurs en France au Moyen Age. Paris: Champion, 1910a.

Faral, Edmond. Mimes français du XIIle siècle. Contribution à l'histoire du théâtre comique au Moyen âge, textes, notices et glossaires. Paris: Champion, $1910 \mathrm{~b}$.

Fotitch, Tatiana, and Ruth Steiner, eds. Les Lais du roman de Tristan en prose d'après le manuscrit de Vienne 2542. Munich: Fink, 1974.

Freeman Regalado, Nancy. “A contract for an early festival book: Sarrasin's Le Roman du Hem (1278)." Acts and Texts: Performance and Ritual in the Middle Ages and the Renaissance. Ed. Laurie Postlewate and Wim Hüsken. Amsterdam and New York: Rodopi, 2007. 249-267.

Freeman Regalado, Nancy. "Performing Romance: Arthurian Interludes in Sarrasin's Roman du Hem (1278).” Performing Medieval Narrative. Ed. Evelyn Birge Vitz, Nancy Freeman Regalado and Marilyn Lawrence. Cambridge: D.S. Brewer, 2005. 103-119

Green, D.H. “Orality and Reading: The State of Research in Medieval Studies." Speculum 80 (1990): 267-280.

Girart d'Amiens. Escanor. Ed. Richard Trachsler. Geneva: Droz, 1994.

Guiron le Courtois. Lais, épîtres et épigraphes en vers dans le cycle de Guiron le Courtois. Ed. Claudio Lagomarsini. Paris: Classiques Garnier, 2015.

Horn, Chloé, Anne Rochebouet and Michelle Szkilnik, eds. Le Pas du Perron fée. Édition des manuscrits Paris, BnFfr 5739 et Lille BU 104. Paris: Champion, 2013.

Huet, G. “Les Traditions Arthuriennes chez le Chroniqueur Louis de Velthem.” Le Moyen Age 26 (1913): 173-197.

Hunt, Tony, and Geoffrey Bromiley. "The Tristan legend in Old French Verse." The Arthur of the French. Ed. Glyn S. Burgess and Karen Pratt. Cardiff: University of Wales Press, 2006. 112-134.

Jean Froissart. Chroniques. Livre III. Ed. Peter F. Ainsworth. Geneva: Droz, 2007.

Jean Froissart. Dit dou Florin. Ed. Anthime Fourrier. Geneva: Droz, 1979.

Johnson, David, and Geert Claassens. "Appendix D." Edward IIl's Round Table at Windsor: The House of the Round Table and the Windsor Festival of 1344. Ed. Julian Munby, Richard Barber and Richard Brown. Woodbridge: The Boydell Press, 2007. 244-268.

Kelly, Douglas. "Narrative Poetic: Rhetoric, Orality and Performance." A Companion to Chrétien de Troyes. Ed. Norris J. Lacy and Joan Tasker Grimbert. Cambridge: D.S. Brewer, 2005. 52-63.

Kindermann, Heinz. Theatergeschichte Europas, Vol. 1: Das Theater der Antike und des Mittelalters. Salzburg: Müller, 1966 [1957].

Kugler, Hartmut. "Artus in den Artushöfen des Ostseeraums." Artushof und Artusliteratur: Akten des Kolloquiums der deutsch-österreichischen Sektion der Internationalen Artusgesellschaft in Rauischholzhausen vom 8. bis 11.10.2008, Ed. Matthias Däumer, Cora Dietl and Friedrich Wolfzettel. Berlin: De Gruyter, 2010. 341-354.

Lacy, Norris. “Emergent Direct Discourse in the Vulgate Cycle.” Arthuriana 4 (1994): 19-29.

Lievois, Daniel, and Baudouin Van den Abeele. "Une ménagerie princière entre Moyen Age et Renaissance: La Cour des Lions à Gand de 1421 à 1641.” Reinardus 24 (2012): 77-107. Loomis, Roger Sherman. "Edward I, Arthurian Enthusiast," Speculum 28 (1953): 114-127. Lupack, Alan. Arthurian Drama: An Anthology. New York and London: Garland, 1991. Mathieu d'Escouchy. Chronique, vol. 1. Ed. G. du Fresne de Beaucourt. Paris: Société de l'Histoire de France, 1863-1864. 
Monson, Don Alfred. Les “ensenhamens" occitans: Essai de définition et de délimitation d'un genre. Paris: Klincksieck, 1981.

Morato, Nicola. “Review: Luca Degl'Innocenti, I Reali dell'Altissimo. Un ciclo di cantari fra oralità e scrittura." Rassegna di Letterature Europea 38 (2011): 194-199.

Moser, Dietz-Rüdiger. "Brauchbindung und Funktionsverlust. Zum Nachwirken der Artus-Tradition in Fastnachtsbrauch und Fastnachtsspiel." Spätmittelalterliche Artusliteratur: Symposium der Görres-Gesellschaft Bonn. Ed. Karl-Heinz Göller. Paderborn, Munich, Vienna, Zürich: Schöningh, 1984. 23-39.

Nykrog, Per. Chrétien de Troyes: Romancier discutable. Geneva: Droz, 1996.

Palmer, Nigel. "Manuscripts for Reading: The Material Evidence for the Use of Manuscripts Containing Middle High German Narrative Verse." Orality and Literacy in the Middle Ages: Essays on a Conjunction and its Consequences in Honour of D.H. Green. Ed. Mark Chinca and Christopher Young. Turnhout: Brepols, 2005. 67-102.

Petit, Aimé. "L'activité littéraire au temps des ducs de Bourgogne: les mises en prose sous le mécénat de Philippe le Bon.” Synergies 2 (2007): 59-65.

Philippe de Novare. Mémoires 1218-1243. Ed. Charles Kohler. Paris: Champion, 1913.

Pickford, Cedric E. L'Evolution du roman arthurien en prose vers la fin du Moyen Age d'après le manuscrit 112 du fonds français de la Bibliothèque Nationale. Paris: Nizet, 1960.

Pickford, Cedric E., ed. Alixandre l'Orphelin: a prose tale of the fifteenth century. Manchester: Manchester University Press, 1951.

Pirot, François. Recherches sur les connaissances littéraires des troubadours occitans et catalans des XIle et XIIIe siècle: Les "sirventes ensenhamens" de Guerau de Cabrera, Guiraut de Calanson et Bertrand de Paris. Barcelona: Real Academia de Buenas Letras, 1972.

Raynaud, Gaston, ed. Les Gestes des Chiprois. Geneva: Fick, 1887.

Richter, Michael. The Oral Tradition in the Early Middle Ages. Turnhout: Brepols, 1994.

Rychner, Jean. La Chanson de Geste: Essai sur l'art épique des jongleurs. Geneva: Droz, 1957.

Saenger, Paul. Space between Words: The Origins of Silent Reading. Stanford, CA: Stanford University Press, 1997.

Sarrasin. Le Roman du Hem. Ed. Albert Henry. Paris: Les Belles Lettres, 1939.

Schlauch, Margaret. "King Arthur in the Baltic Towns." BBIAS 11 (1959): 75-80.

Schulze-Busacker, Elisabeth. "Gauvain li mauparliers." Lancelot, Yvain, Gauvain: Colloque Arthurien Belge de Wégimont. Paris: Nizet, 1984. 113-123.

Selzer, Stephan. Artushöfe im Ostseeraum. Ritterlich-höfische Kultur in den Städten des Preußenlandes im 14. und 15. Jahrhundert. Frankfurt a. M.: Lang, 1996.

Sorbin, Arnaud. Histoire contenant un abrégé de la vie, mœurs, et vertus du roy tres-chrestien et debonnaire Charles IX. Paris: Guillaume Chaudière, 1574.

Spitzer, Leo. "Marie de France - Dichterin von Problem-Märchen." Zeitschrift für romanische Philologie 50 (1930): 29-67.

Stanesco, Michael. Jeux d'errance du chevalier médiéval. Aspects ludiques de la fonction guerrière dans la littérature du Moyen Age flamboyant. Leiden: Brill, 1988.

Summerfield, Thea. "The Function of Fiction: King Edward I, King Arthur and Velthem's Continuation." Journal of the International Arthurian Society 3 (2015): 32-54.

Tailby, John E. "Arthurian Elements in Drama and Meisterlieder." The Arthur of the Germans: The Arthurian Legend in Medieval German and Dutch Literature. Ed. W.H. Jackson and Silvia A. Ranawake. Cardiff: University of Wales Press, 2000. 243-247. 
Taylor, Andrew. Textual Situations: Three Medieval Manuscripts and Their Readers.

Philadelphia, PA: University of Pennsylvania Press, 2002.

Trachsler, Richard. "Formulas, Orality and Arthurian Romance: A Short Note on a Long Story." Romanic Review 100 (2009): 415-429.

Tyssens, Madeleine. "Le jongleur et l'écrit." Mélanges offerts à René Crozet à l'occasion de son soixante-dixième anniversaire par ses amis, ses collègues, ses élèves et les membres du C.E.S.C.M., vol. 1. Ed. Pierre Gallais and Yves-Jean Riou. Poitiers: Société d'études médiévales, 1966. 685-695.

Vale, Juliet. "The Late Thirteenth-Century Precedent: Chauvency, Le Hem, and Edward I." Edward III and Chivalry: Chivalric Society and its Context 1270-1350. Woodbridge: Boydell, 1982. 4-24 and Appendices 1-9.

Wilhelm, James, ed. The Romance of Arthur, III: Works from Russia to Spain, Norway to Italy. New York and London: Garland, 1988.

Zumthor, Paul. La Lettre et la Voix. Paris: Editions du Seuil, 1987.

Zumthor, Paul. La Poésie et la voix dans la civilisation médiévale. Paris: Presses Universitaires de France, 1984. 
Bereitgestellt von | UZH Hauptbibliothek / Zentralbibliothek Zürich 